\title{
From the History of a Book to a "History of the Book"
}

\section{Citation}

Price, Leah. Forthcoming. From the history of a book to a "history of the book." Representations 108.

\section{Published Version}

http://ucpressjournals.com/journal.asp?j=rep

\section{Permanent link}

http://nrs.harvard.edu/urn-3:HUL.InstRepos:2641801

\section{Terms of Use}

This article was downloaded from Harvard University's DASH repository, and is made available under the terms and conditions applicable to Other Posted Material, as set forth at http:// nrs.harvard.edu/urn-3:HUL.InstRepos:dash.current.terms-of-use\#LAA

\section{Share Your Story}

The Harvard community has made this article openly available.

Please share how this access benefits you. Submit a story.

\section{Accessibility}


Leah Price

From The History of a Book to a "History of the Book"

One way to describe "the way we read now" is to say that we don't. This isn't to deny that in a changing theoretical landscape, reading remains a constant: English professors continue not only to read, but to use the gerund as a synonym for "literary-critical interpretation." Even as successive aspects of late-twentieth-century symptomatic reading come under attack-- its granularity (Franco Moretti's "distant reading"), its adversarial stance (Eve Sedgwick's "recuperative reading"), the wedge it drives between surface and depth (Sharon Marcus's "just reading")--a familiar noun anchors each new adjective (Moretti), (Sedgwick), (Marcus, Between Women).

If "we" is taken to encompass the humanities and humanistic social sciences more generally, however, then "reading" is no longer the name of our game. In the twentieth century, the premise that any object could be read spawned new disciplines like semiotics and cultural studies; in the twenty-first, no journal would accept an article called "Reading a Mid-19thcentury, Two-Cylinder Parlor Stove as Text." ${ }^{\mathrm{i}}$ No longer do "disciplines from political science to anthropology, and from economics to legal and juridical studies," in Fredric Jameson's words, "take as [their] model a kind of decipherment of which literary and textual criticism is the strong form" (Jameson 297). A keyword search in JSTOR registers the semantic shift: gummed up at first with red herrings in the form of "Reading the Representation of Y" or "X: A Reading," the list thins around the turn of the millennium to a trickle of articles about literacy.

The balance of trade has shifted: literary critics now look to other fields not for raw materials but for methodological tools. Where the humanistic social sciences once borrowed literary-critical tricks to interpret non-textual objects, literary critics today mine other disciplines-bibliography, history of science, even archaeology--for a vocabulary in which to describe the non-textual aspects of a particular category of material object: books. Instead of "reading" sewer systems, critics now smell leather bindings. ${ }^{\text {ii }}$ Far from "reading" the stock market, we tabulate paper prices. As the metaphor lost its export value, critics began to abandon the thing itself.

Literary theory lasted barely more than a decade as queen of the disciplines. Its reign was both foreshadowed and survived, however, by a broader tradition in which the alphabetic practices inculcated by formal schooling supplied the template (in Lorraine Daston's words) "for other ways of making sense of objects quite different from the manuscript or printed page--the morphology of a plant, the trajectory of a comet, the slide under a microscope, the 'reading' of an instrument. This would have been especially the case for those who--for reasons of class, gender, and the cultural status of literacy--would have learned bookish skills before or to the exclusion of manual ones" (Daston 444). Daston achieves more distance than Jameson from the logic that both describe, for the word "before" slyly inverts the received wisdom that positions manual skills as a given, textual operations as a supplement. Yet in positioning physical gestures as the alternative to textual operations, she leapfrogs over the manual dimension of reading itself: the handling of books, the turning of pages. Like Jameson's "model," moreover, Daston's "template" remains double-edged: both endow written texts with exemplarity at the price of stripping them of specificity.

In this context, the bibliographical turn begins to look less like a flight from reading than like a war on metaphor. For a hermeneutics of suspicion, substitute a poetics of deflation: the shift from text to book implies a slide from the literary to the literal, from the abstract to the concrete. In the process, critics change from the freest of associators to the most slavish of idiots 
savants. A dogged (or mulish) taste for the mundane, the contingent, and the simple-minded finds its only outlet in puns. Writing from the "margins" gave way to writing in the margin (adversaria provide much of the richest book-historical evidence). The old refrain "it is no accident that" was shunted aside by a new interest in paratextual "accidentals." Isobel Hofmeyr reinvested post-colonial catchwords like "stereotype" and "cliché" with their typographical weight (Hofmeyer and Nuttall). And Peter McDonald retranslated the slogan Ail n=y a pas de hors-texte@ into a claim about tipped-in pages (McDonald 222-23). In foregrounding the technical sense of Derrida's term, McDonald defines the text by contradistinction to the book, not the world.

In a discipline that prides itself on discerning hidden depths, superficiality shocks like a purloined letter. Even the repressed is brought down to earth when a scholar notices that in the list of goods that he brought to Walden Pond, Thoreau omits the one whose trace it constitutes: a pencil. ${ }^{\text {iii }}$ Once, a writing instrument would have stood for something less speakable; now, selfreference finds its home in an everyday tool. The hand upstages the brain.

I spoke just now of a flight from metaphor, but the opposite case could also be made: that where literary critics once invoked a metonymic logic to discuss commissioning, writing, editing, printing, and reading -- studied in relation to particular works, whether upstream as in textual notes or downstream as in reception histories -- book historians have shifted toward a metaphoric logic in which reading is compared to other forms of consumption, or writing to other manual practices, or copyright to other forms of property. When Daston brackets the page with a comet, she looks both backward to the long tradition that exalts reading to an art that other interpretive practices can only hope to emulate, and forward to new forms of scholarship that reduce the book to just another object. Thus, where intellectual historians once studied the notetaking habits of individual thinkers, Ann Blair and Peter Stallybrass instead analyze scholarly note-taking side by side with commercial record-keeping; where critics once narrated authors' alcoholism (or analyzed the literary figure of the drunkard), Paul Duguid traces the history of authorial signature in parallel to the history of wine branding; and where an earlier generation of "law and literature" scholarship examined the image of lawyers in Romantic poetry, William St. Clair juxtaposes the development of copyright with the changing legal regimes governing the sale of pharmaceuticals (Blair; Blair and Stallybrass; Duguid; St. Clair). In cutting across different objects (books and ledgers, books and bottles, books and pills) to identify parallel practices, this research topples the text from its taxonomic pedestal.

More narrowly, it raises questions about the relation of a particular practice (reading) to a particular object (the book). "The history of books and reading" is now a catchphrase, and many scholars in flight from lexical monotony refer to "the history of the book" interchangeably with "the history of reading." But while it's true that both share an opposite term -- the history of literature or of ideas -- the survey I've just offered of the metaphorization of "reading" and reliteralization of bibliographic terms suggests what gets lost in that lumping. Where latetwentieth-century critics insisted that objects other than books could be read, so early-twentyfirst-century scholars are rediscovering (like so many M. Jourdains) that books can be subjected to uses other than reading. This article raises two questions: how can scholars make sense of the full range of operations in which books are enlisted (including but not limited to reading); and what difference does it make whether we structure that enquiry around the human subjects who perform those operations, or around the inanimate objects that undergo them?

Let me begin with the second problem. No matter how energetically they distance themselves from the esthetic, book historians remain as attached as literary historians to 
narratives centered around human agents: the author, the editor, the reader, or (even more literally) the literary agent. Such scholarly accounts mirror the structure of their sources, whether authors' biographies, company histories, or readers' memoirs. They also recapitulate a more diffuse tradition B both religious (specifically Augustinian) and literary (specifically Wordsworthian) -- which relies on the encounter with a book to account for the development of a self.

Even when book historians choose objects that stand outside of the literary, the language in which they describe their own scholarly practices remains parasitic on a literary canon in which reading gets tirelessly thematized. The final section of this article argues that a particular corner of that canon, the Bildungsroman, has both generated and limited the stories scholars tell about reading. First, though, I want to ask where else we might look for models that make the book narratable. My claim is that the most productive overlap between recent book-historical scholarship and the longer tradition of bibliographically-themed lifewriting lies not in their common interest in human subjects, but rather in their shared attention to the circulation of things. Analytical bibliographers have taught us that books accrue meaning not just at the moment of manufacture, but through their subsequent uses: bought, sold, exchanged, transported, defaced, mended, sorted, catalogued, stored, ignored, collected, neglected, discarded, recycled. A history of the book that took these transactions as building-blocks (rather than focusing on the fraction of the book's lifecycle that it spends in the hands of readers) could usefully borrow its formal conventions from the "it-narrative": a fictional autobiography in which a thing traces its travels among a series of richer and poorer owners.

When late-twentieth-century critics rediscovered the it-narrative, they were thinking of an eighteenth-century genre, one whose life begins in 1709-10 (the date of Charles Gildon's Golden Spy) and ends less than a century later. By 1800, its babbling banknotes, canting coins, prosing pocket-watches and soliloquizing snuffboxes seem to have talked themselves out. In the decades hopscotched over by those critics, however, it-narratives never stopped being read, or even written B with two differences. First, the guineas, rupees, and banknotes whose histories, adventures, and lives had formed the genre's stock-in-trade were now replaced by books; and instead of addressing middle-class adults, it-narratives now went downmarket to those too young, or too poor, to choose the books they owned. Although some had always trickled down to children, eighteenth-century it-narratives were adult -- often in the strong sense of the word. (Crébillon's Le sopha (1742) or Diderot's Les bijoux indiscrets (1748) prefigure Prince Charles's latter-day it-fantasy of being reincarnated as a tampon. ) After 1800, the genre became G-rated: witness The History of a Religious Tract Supposed to be Related by Itself (1806); The History of an Old Pocket Bible (1812); Adventures of a Bible: Or, the Advantages of Early Piety (1825); The History of a Pocket Prayer Book, Written by Itself (1839); The Story of a Pocket Bible (1859); The Story of a Red Velvet Bible (1862); Handed-On: Or, the Story of a Hymn Book (1893). Moving from one kind of printed paper to another, the it-narrative shadowed two competing disciplines: first numismatics, then bibliography.

As good books replaced bad coins, officious thing-exposition upstaged confidential thing-confession. But religious books weren't the only ones that talked, nor evangelical publishers the only ones who gave them voice. As late as 1873, a copy of Robinson Crusoe could narrate Annie Carey's heavily-illustrated account of papermaking and binding, The History of a Book, commissioned by the same firm that had published her earlier Autobiography of a Lump of Coal; A Grain of Salt; A Drop of Water; A Bit of Old Iron; and A Piece of Old Flint 
(1870).

Two innovations united both strands of it-narrative (religious and scientific). One was that in neither case did the end user correspond to the buyer: whether gifts presented to children by their parents, or tracts thrust upon poor adults by philanthropists, both reached readers through a more than purely commercial transaction. The other was that both shared a new kind of protagonist. Where banknotes had once exemplified circulation across class lines, paper now changed hands in the form of bibles, hymnbooks, prayerbooks, tracts.

To anyone familiar with the classic phase of the it-narrative, this bibliographical turn will come as a surprise. But the talking book doesn't come out of nowhere, for eighteenth-century object narratives already allude to the life-cycle of books. In the most famous of all it-narratives, Chrysal, or, The adventures of a guinea (1760-65), the narrator of the preface happens on a fragment of "some regular work" in the paper wrapping the butter served to him by a poor family; he goes on to seek out more of the same manuscript by going to the chandler's shop that they patronize, "as if for some snuff, which, as I expected, was given me on a piece of the same paper" (Johnstone and Bosse x-xi). As Christina Lupton has argued, the classic it-narratives are "in the first place, the life story of a pile of paper, and only in the second, the story of the objects represented there" (Lupton 412). In Adventures of a Black Coat a manuscript is used as a potholder, and in Adventures of a Banknote, an author can't even afford enough coal to dispose of his rejected verses--although his neighbor later burns them to revive him from a concussion. Christopher Flint has read it-narratives as an allegory of authorship, arguing that--"the speaking object figures the author's position in print culture" (Flint 212). Reading backward from the nineteenth century, however, eighteenth-century it-narratives look less invested in a figurative representation of the author than in a literal representation of the book. To the extent that early itnarratives frame themselves as found objects, they already emphasize the circulation of paper.

All that changes is where that emphasis occurs. In the first generation of it-narratives, the book-object is mentioned around the edges: in prefaces, introductions, and other paratexts. Only around 1800 does its representation migrate from frame narrative to plot. If eighteenth-century it-narratives taught readers the rules governing cash and credit in a commercial society, the Stories, Histories, and Adventures that straggle in after 1800 take on a narrower topic: how one very particular kind of paper should be bought, sold, given, borrowed, and disposed of. More specifically, it-narratives commissioned by religious publishers struggle to reconcile the competing imperatives of a person's relation to his books (imagined as less alienable than other belongings) and a person's relation to other persons (vehicled, in the world that tracts both represent and inhabit, by the exchange of printed matter.)

After 1800, as secular it-narratives shifted their focus to manufacture, religious publishers kept alive the genre's traditional emphasis on circulation. What mechanical technologies are to one, social relations are to the other. Talking tracts allot as little space to their own conception as any human narrator does: only a secular volume like the 1873 History of a Book could end, Tristram Shandy-like, at the moment when its narrator first goes on sale. In asking how books are shared (and only secondarily how books are made), it-narratives put out by evangelical publishers anticipate the 1847 pamphlet that urged the Religious Tract Society (RTS) to stick to its professed aim of "circulation, leaving production to individuals" (Power of the Press 39, quoted [Fyfe 40]).

The formal conventions of it-narrative thus mimic the ideological mission of its publishers: the Religious Tract Society, founded for the purpose of moving books across classes and even continents, called for books to be "used, worn out, and worn to pieces."iv Handling 
trumps hoarding; books should be transferred, not treasured. As speaking books replace speaking coins, the Enlightenment faith in exchange gives way to its Christian equivalent -- the hidden hand to the parable of the sower. The it-narrator of one American History of a Bible tells us nothing about the moment of its making, choosing instead to begin its life story at the moment when a buyer "liberates" it from being a "close prisoner" in a bookseller's shop. Elated when praised for "the elegance of my dress" (that is, binding), the bible soon discovers that its new owners "would not permit me to say one word": instead, these "jailors" force it "to sit upon a chair in the corner of the room" (History of a Bible, 1). One owner, worried that the bible will turn her son into an "enthusiast," "in the heat of passion locked me into my old cell, where I remained in close confinement" (5); others "joined in scandalizing my character; and I was again confined to my old cell" (6). To be read, in this metaphor, is to be "discharged from prison"; even the glass front of the bookcase becomes a "prison door," whose locking and unlocking determines that narrator's fortunes (7).

The evangelical imperative to circulate dovetails neatly enough with the secular logic that privileges use above display, reading above collecting. That convergence makes it doubly puzzling, however, that not every bible seeks out readers as wholeheartedly as does the narrator of the History. A tug-of-war between circulation and stasis structures the Story of a Pocket Bible published in London half a century later. Given to a child on his birthday, willed to a spendthrift, unloaded onto a bookseller, windowshopped by a laborer, bought for the sake of its binding, inherited by a profligate, passed along to his sick sister, stolen by her servant, resold to a Aromanist merchant@, stumbled on by a houseguest, stomped on by a priest, cast into prison along with its owner, auctioned to a tradesman for use as wrapping paper, donated by a pious bookseller to a godless chartist, shoved under a floorboard by the chartist=s Catholic wife, trampled (a second time) by striking workmen, traded for a dram, its peripatetic narrator ends up, like a foundling in romance, rescued from a used bookshop by its original owner=s children (Sargent). By this point, the book is not secondhand, but nineteenth-hand: a picaresque narrator must always move on.

Like the title of Handed-On: Or, the Story of a Hymn Book, the plot of the Story of a Pocket Bible centers on perpetual motion. Yet every step the narrator takes has violence and theft for its mechanisms, death and bankruptcy for its catalysts. This may help explain why the Pocket Bible worries less about being consigned to solitary confinement than about falling into the wrong hands. The History of a Bible's "close confinement" is matched by the Pocket Bible's equally long stint on a "shelf of banishment"; we might therefore expect a sigh of relief when, after weeks gathering dust on a licentious gentleman's bookshelf, the narrator finds a duster approaching, closely followed by a hand. Instead, it shrinks from the servant's advances:

After looking around in her trepidation, and wiping her hands with her apron, she mounted on a chair, and reached me from my shelf of banishment... It was not right; none have so emphatically condemned the slightest approach to unfaithfulness in servants as I... Had this poor girl, therefore, been better acquainted with me, she would scarcely have ventured to seek an interview at that time ... Those stolen minutes of communication were improper; and on one occasion, I had it in my power to hint as much to her. I was recounting the duties of the various classes of persons to whom I had messages to deliver, and among other things I had something to say to servants. "Servants," I said, "obey in all things your masters...@ Hannah blushed deeply when this reproof reached her.... She hastily replaced me; and after that, though she cast many longing looks towards me, she 
did not take me again from my place of repose. (38)

Nothing less Augustinian: instead of being converted through reading, the maid is converted to not reading. Where one conversion begins with the phrase "tolle lege," the other ends with the decision not to "take" (or read) the book. At least, not the master's copy on the master's time: the language of stolen interviews and stolen minutes makes it hard to remember that the volume itself never leaves the room.

We all know the long literary tradition that privileges mental operations over manual ones, associating handling with either the female servants who dust books, the tradesmen who tear them apart to wrap groceries, or the even more vulgar nouveaux riches who display them on sofa-tables. In this case, the cheapness of the tract in which the anecdote is contained -- a tract whose implied reader shares Hannah's class position even if its implied buyer is likelier to resemble her master -- makes it all the more striking that the maid who turns her mind to the pages is urged to turn her duster to the binding. By the end of this paragraph, the talking Bible almost recoils from being read: what was introduced as "my shelf of banishment" is now dubbed "my place of repose."

To be fair, what the pocket bible forbids Hannah to read isn't the Bible so much as a bible -- a book, not a text. "Hannah did not rest satisfied," the narrator adds, "until she had procured the services of another of my own family - the very counterpart of myself, indeed, except in mere externals." (38). The universality of the bible's content paradoxically depends on the variability of its "externals" -- lettering, binding, paper, size. But the fact that this humbler "counterpart" never gets to tell its story shortcircuits the self-referential conceit with which the History of a Pocket Bible began. These are books about books, to be sure, but they are also cheap tracts about expensive bibles. The History of a Red Velvet Bible is covered with paper, not velvet; the Pocket Bible that considers itself too good for a servant to read narrates nothing better than a shilling tract -- a tract whose implied reader shares Hannah's class position, even if its implied buyer is likelier to resemble her master. Conversely, even the cheap tracts that invite readers to "wear [them] to pieces" show unremarkably few traces of use: across the several dozen copies of the genre that I've been able to examine, wax and smoke stains are surprisingly absent, let alone intentional marks like underlining or turned-down corners.

Even more paradoxically, the aspirational book vehicles a text that slums. Composed by middle-class (or adult) writers mimicking the voice of uneducated (or not yet educated) readers, the language of tracts talks down; in contrast, the material forms that it represents are both more durable and more upmarket than those it inhabits. Bibliographical "externals" short-circuit linguistic content: the form of the object undermines the circularity on which the text's feeble humor depends.

When the Pocket Bible worries that the circumstances under which it's read will cancel out whatever "messages" it contains, it echoes debates among religious publishers about how to diffuse good books without pauperizing or even corrupting their recipients (Howsam). Would replacing subsidized market mechanisms by free distribution networks allow sacred books to transcend the commercial, or on the contrary lead readers to dismiss them as waste paper? Did the need to save up for the price of a book make it more or less likely to be read? Was tractdistribution a means to the end of establishing personal connections between giver and receiver, or were such interpersonal transactions only a means to the end of launching books into circulation? 
It-narratives remain torn between subject and object, relations among readers and relations with books. The history that, as we say today, "personalizes" belongings -- a bond that the booktrade enshrined earlier in the phrase "association copy"--tugs against the human relationships that can be forged only in the process of alienating possessions: lender and borrower, buyer and seller, carrier and pickpocket, Sunday-school teacher and pupil (Plotz); (Fliegelman). The stop-and-go rhythm of it-narratives registers this double bind. At moments when characters treat their book as a "friend" or "companion"--metaphors that project the anthropomorphic logic of the genre onto the world represented within it--the plot stands still. Only when characters reduce their book to a commodity valued for no more than it can fetch at the pawnshop do they come into contact with other characters; only then can narrative give way to dialogue. No surprise, then, that books should balk not only at being stolen, but even at being sold. When the hero of the History of an Old Pocket Bible (published in the Methodist Cottage Magazine; or, Plain Christian's Library in 1812) is exchanged for a ribband, its only consolation is to remind itself that "Judas sold his divine master for thirty pieces of silver" (The History of an Old Pocket Bible 129). The narrator of the History of a Religious Tract Supposed to Be Related by Itself secularizes the metaphor, complaining that "very soon after I came into the world I was sewn up into a book, and sent to a certain Depository in Stationers' Court, where I was exposed to sale with as little remorse as cattle in Smithfield, or Negroes in a slave market" (The History of a Religious Tract Supposed to Be Related by Itself, 1).

To be read is to be enslaved, violated, objectified, commodified -- metaphors dramatized most starkly in "The Life and Adventures of a Number of Godey's Lady's Book. Addressed Particularly to Borrowers, Having Been Taken Down in Short-hand from a Narration Made By Itself, When the Unfortunate Creature Was in a Dilapidated State, from the Treatment Received at the Hands of Cruel Oppressors." ${ }^{1}$ Here, the autobiography of a number of Godey's appears in - a number of Godey's; what's more, the conditions under which Godey's is bought and borrowed form its subject. "You must not suppose that I was always the wretched, coverless, soiled, dog'seared and torn object you see," the narrative begins: "I was an intellectual individual. I knew it; I surveyed my own cover with a proper degree of pride, a little abated, however, by the reflection that I could be bought and sold for twenty-five cents." Unlike the Pocket Bible and Religious Tract, however, the Number of Godey's is not complaining about the fact of being put up for sale. On the contrary, its ambition is to fetch an even higher price: "I felt I was worth, at least, a dollar; and to dispose of me for less was a poor reward for all my wit and wisdom" \{, 1855 \#4606@425\}. The question here is not (as in the Smithfield metaphor) whether books should be conceptualized as something more or less than commodities, but -- more technically -- whether the transaction through which they change hands should consist of buying, renting or borrowing. "When in the course of human events," the narrator declaims, "it becomes necessary for people to borrow boot-jacks, salt, or cucumbers, let boot-jacks, salt, or cucumbers be loaned. But let indignant subscribers to the 'Lady's Book' declare their independence of borrowers" (427).

That commercial message drives the complaints that structure its "Life and Adventures": "One visit would lose me a leaf, another a plate. ... My music got enamoured of a piano at my fifth stopping-place, and shamefully deserted me forever. The great gap you see on one of my pages was occasioned by the scissors of a young lady, who clipped out a beautiful poem, by Mrs. Neal, for her scrap-book. ... One careful housewife, to complete my degradation, after she had read my contents, used me as a duster" (426). Where the Pocket Bible's reluctance to circulate contradicts its evangelical mission, the equivalent structure makes perfect sense in a magazine story designed to boost sales. After parting mournfully from an honest schoolmaster, "never to 
look on his face again," the Number of Godey's complains that the thoughtless girls whom he teaches demand to have his copy passed along to them, on pain of being fired by their fathers. A dialogue between two of his pupils drives the point home:

"What! Injure a man because he hesitated to suffer you to use his property as freely as though it were your own?"

"But, it is only a book." "Very true, and that yonder is only a bonnet. How would you like to have that passing from head to head, when it came from the milliner, being borrowed in turn by all the girls of the village."

"Yes, but a bonnet is a necessity."

"And the "Lady's Book" becomes a necessity very soon: it is mental food" (426).

Women read, but men buy: even the goody-goody who refuses to join the 28 women who club together for a single subscription cites the authority of her father, who thinks so highly of Godey's that he has given her permission to take out her own subscription. When the schoolmaster laments that "the copy I have to pay for" is extorted by girls who "spend yearly, on folly, more money than would suffice to support me," he endorses the very equation between person and thing on which this blackmail depends: the "yearly ... money" could just as well be the narrator's name for the annual cost of supporting (that is, subscribing to) itself.

The structure of it-narrative, then, is used to reframe a debate about the rights of persons (in this case, publishers) as one about the rights of objects (in this case, magazines). Where the Religious Tract is insulted at being bought, the Number of Godey's is wounded instead by a kind of bibliographic promiscuity in which it's forced to serve the pleasures of more successive subscribers than it can stand. Beginning its life "dressed by the binder," the Number ends up with "my cover taken entirely off, leaving me in a distressing state of nudity." If clothing is both personal and subject to an annual fashion cycle -- who would wear a second-hand bonnet? -- so are magazines. To pass "from hand to hand" is to be sullied. Like the Religious Tract, the Quire of Paper, the Old Pocket Bible, and the Book, the Number of Godey's feels most vulnerable at those moments where it's endowed with skin that can be scarred or limbs that can be amputated:

The brown mark on one of my corners came from the hot ashes of a cigar. Every step that I took was marked with fresh indignity and additional mutilation. ... Here I am, prematurely old, and ready to fall to pieces from continued ill treatment. At one house I would find the face of one of my plates, smudged with candy from a child's fingers; at another, the eyes of a lady in the fashion plate was ornamented with an enormous pair of spectacles. (426).

No matter whether the narrator's wounds are metaphorical (inflicted on the bodies it resembles) or metonymic (inflicted on the bodies it represents). The topic that moves books to speech is the wear and tear to which they have been subjected. "The History of an Old Pocket Bible" begins, "I am at present in a most tattered condition. One of my covers has long since been missing, and the other hangs only by a single thread. A great part of my leaves are torn out, and the remainder are so doubled down and spoiled as scarcely to be legible. Indeed I daily expect to be cast into the flames" ("The History of an Old Pocket Bible" 89). The narrator of The History of a Book introduces its description of the printing process by punning that "I was yet to undergo a great deal of sharp usage" (Carey 141). The eponymous Quire of Paper translates that bruised and battered condition more specifically into a loss of voice.

What horrors I endured when after being borne through several dark apartments, I saw before our eyes a dreadful machine, whirling round with terrible velocity, and 
roaring with so loud and tremendous a voice for prey that every ear was deafened, and every sound lost near it! Think what my situation must have been, when I discovered that $I$ was the kind of food this monster craved for, and amongst the number of its devoted victims. All language were weak to describe to you the terror and anguish I felt when I was thrown between its gaping and voracious jaws. ("Adventures of a Quire of Paper" 449)

The physical violence of being mangled is doubled by the psychic violence of being silenced. Yet the indignity of a literal voice being drowned out by a machine's metaphorical "roar" is undermined by the fact that that voice belongs to an equally inanimate object: if the narrator's "language [is] weak," what else could we expect from a sheet of writing-paper?

If the happiest women have no history, the same could be said of the happiest books (Eliot 400). Conversely, it-narrators must suffer, because the only voice with which prosopopoeia can invest them is the passive. In secular accounts of book production, the narrator gets pressed, trimmed, and beaten with a hammer (Carey 137); in religious accounts of book circulation, the narrator gets pawned, stolen, torn, kicked, and trampled on (Sargent). No sooner does the narrator of the 1873 History of a Book begin to "feel that I was coming out of the rudimentary and fragmentary state of my existence; that my individuality was beginning to assume a definite shape and form"--that, in short, we are moving briskly beyond the "first remembrances of myself" which "date from a certain stage in my manuscript life--an insubstantial, loose, unbound condition of existence"--than events puncture its sense of self: "Not for long was I allowed to remain in this inflated state of mind with regard to my probable size as a book. My sheets were taken and ... passed between two iron rollers... This 'rolling-machine' compresses the sheets so very much more than the old 'hammering' did [that] the result, to my mind, was to make me 'feel small'" (Carey 137). In the Adventures of a Bible (1813), a characteristically Christian reversal makes that very smallness a source of power: "'I was indeed but six inches in height," acknowledges the narrator; "but with this I was by no means discontented, as I thought that, probably, I should be more frequently brought into use, than if I had been of a larger size; and I knew that, small as I was, I could teach and do as much as the largest" (6).

A voice that emerges from a body small enough to be overlooked; a narrator that eloquently analyzes its sensations but can't talk itself out of a beating (or a rolling or a hammering); a narrator whose physical pain is compounded by the humiliation of being silenced; a narrator, more fundamentally, whose subjectivity is never acknowledged by other characters: if the it-narrative's combination of strong focalization with represented weakness sounds at once counterintuitive and familiar, the reason may be that the same contradiction vertebrates a betterknown genre, the Bildungsroman. Each genre endows its narrators with consciousness while stripping them of power; each contrasts the narrator's fluency with other characters' refusal to recognize its standing to speak. ${ }^{\mathrm{V}}$

"If you would know how a man treats his wife and his children, see how he treats his books": a book that's been used to pieces reflects as badly on its owner as does a book that's respected to the point of not being used at all. Emerson's oft-quoted aphorism casts the book as a vulnerable being, quick to feel but unable to protect itself. A sensitive yet powerless protagonist who forms the object rather than the subject of action, a camera eye whose plight serves as an index to those social actors with whom it comes into contact: if it-narratives draw at once on 
slave autobiography (as in the History of a Religious Tract Supposed to Be Related by Itself) and seduction plots (as in the "longing looks," "blushes," and "stolen moments of communication in the History of a Bible, or the Godey's Lady's Book's descent from pride in its fine clothing to humiliation at the violation of its body), they would go on to be drawn upon by the Bildungsroman and the narrative of animal rights. Whether the seduced women upstream of itnarrative or the child narrators downstream, the "wife and children" of Emerson's analogy mirror the book's ability to sift the virtuous (who recognize its subjectivity) from the vicious (to whom it remains a tool).

It would be stating the obvious to acknowledge that bildungsroman and it-narrative stand at opposite poles of Victorian fiction: one on the rise, another on the wane; one centered on subjects, the other on objects. In placing them in parallel, however, I'm only following the example of much recent research on it-narrative, which mines the genre for intertexts to more familiar works of (human-narrated) fiction. Thus, Jonathan Lamb and Lynn Festa have described slave autobiography as giving voice to a piece of property, Michael Gamer has interpreted Edward Waverley's wanderings as a riff on it-narrators' circulation, and Paul Collins has reclassified Black Beauty as at once an it-narrative whose object happens to be animate and a slave narrative whose hero happens to be equine (Lamb 158), (Festa), Gamer, unpublished paper; see also (Collins These readings take as their benchmark the earlier, numismaticallythemed phase of it-narrative. The Bildungsroman borrows something far more specific from later it-narratives: in both cases, I want to suggest, questions about agency are routed through a particular category of object, the book. In the absence of time to prove this case, I'll take as my example a text that anyone likely to read this paper will know well enough to dispense with proof -- that is, David Copperfield.

The plot of this novel can be schematized easily enough as a progression from the child who is written upon to the adult who writes. In a passage uncannily echoed by the History of a $\underline{B o o k}$, David explains that Aa profound impression was made upon me by the roar of voices in the schoolroom suddenly becoming hushed as death when Mr. Creakle entered ... looking round upon us like a giant in a story-book" ([Dickens 90], my emphasis). The shift from noise to book will make perfect sense a moment later, once it becomes clear that the schoolmaster's ruler will come in handier for marking skin than for lining paper. But love, no less than hate, reduces the young David to a writing surface. When Dora traces the wrinkles on his forehead with a pencil, "putting it to her rosy lips to make the mark blacker," maturation changes from a problem of depth psychology (how can David's mind make a mark on the world?) to the most superficial of phenomena (how can David's skin be marked by pencils, rulers, chalk and ink?) (586). Printed upon like a page, ruled like a sheet of paper, scanned like a spine, and "rubbed out" like a slate, David is also tagged "in indelible marking-ink@ $(91,206)$ and bound between boards--inscribed, not with an author and title, but simply with the plot summary "he bites."

The teachers who mark David's skin like a book take a cue from those earlier adults who mark it by a book. "I had a greedy relish for a few volumes of voyages and travels--I forget what, now," the narrator tells us,

and for days and days I can remember to have gone about my region of our house, armed with the centre-piece out of an old set of boot-trees - the perfect realization of Captain Somebody, of the Royal British Navy, in danger of being beset by savages, and resolved 
to sell his life at a great price. The Captain never lost his dignity, from having his ears boxed with the Latin Grammar. I did. (60)

Sharon Marcus has described Jane Eyre in terms of a series of faceoffs between a child who uses the book as a prompt for mental withdrawal and adults who enlist it to jolt her back into a painful awareness of her body (Marcus, "The Profession of the Author: Abstraction, Advertising, and Jane Eyre" 209). Dickens, too, pits the child's textually-occasioned abstraction against adults' bibliographically-assisted intrusions. When David=s mind wanders in church, AMiss Murdstone pokes me with her prayer-book@ (57); when it wanders at home, she "takes the book, throws it at me or boxes my ears with it@ (59). The text remains in David=s head even after the volume of travels has left his hands; conversely, the Murdstones handle books instead of internalizing their contents. The metonymic logic of the boxed ears and the poked side will eventually give way to the metaphoric logic of the inked forehead and the rubbed-out welts. In both cases, though, the book's encounter with the body upstages the text's with the mind. Neither impression goes more than skin deep.

What difference does it make whether narrative is focalized through a child impressed by others, or through a book endowed with self-expression? Whether to follow a mind stamped by texts or a book marked by hands is not just the problem of David Copperfield or the History of a Pocket Bible. Historical accounts, as much as fictional ones, need to decide whether to situate agency with books or their users.

I've described Victorian fiction forking into one subgenre (the it-narrative) that recycled earlier novelistic conventions and another (the Bildungsroman) that trickled down into later fiction, biography and even historiography. It might be safer, however, to identify the division of labor between those two subgenres as the most durable legacy of nineteenth-century fiction. If it-narrative corresponds to the bibliographical project that tracks the provenance and transmission of a particular printed copy, then the Bildungsroman bears a closer resemblance to those methods that chart the development of an individual's literary sensibility (whether under the names of reception history or of close reading) (Darnton). No matter whether that individual is a historical figure like Carlo Ginzburg's Menocchio or Darnton's Ranson or John Brewer's Anna Larpent--readers whose diaries, letters, or inquisitorial files have deposited a record of response--or is the critic in propria persona.

In those scholarly traditions no less than in the Bildungsroman, the guiding thread remains a human subject's formation through a series of texts. Analytical bibliography and itnarrative substitute an object's accretion of meaning via a series of uses. One is structured by the growth of a child's mind (caused or at least catalyzed by books), the other by the aging of a book (worn out as it passes from hand to hand). Competing Victorian fictional subgenres thus anticipate twentieth-century scholars' oscillation between tracking persons and tracing objects. One could be aligned with Darnton's "communications circuit," structured around human agents such as bookseller, author, smuggler, and binder; the other with Thomas Adams and Nicolas Barker's alternative paradigm, which reduces humans to stations along the path that the book follows from commissioning, to composition, manufacture, circulation, and disposal (Adams and Barker 12, 15).

More narrowly, it-narrative could offer a precedent for the internalist account of reading audiences that Roger Chartier has called for -- urging book historians to look, not at the reading habits of a group defined by "a priori social oppositions," but rather at "the social areas in which 
each corpus of texts and each genre of printed matter circulates" (Chartier 7). In this model, the book would exemplify Arjun Appadurai's argument that while "from a theoretical point of view human actors encode things with significance, from a methodological point of view it is the things-in-motion that illuminate their human and social context@(Appadurai 5).

The it-narrative, I've suggested, bequeaths a powerful set of conventions to the Bildungsroman--even if a formal gimmick in the first becomes an ethical commitment in the second. Another place to look for the legacy of the genre, however, is in non-fiction discussions of the book, both in their own time and after. The habit of slotting books into roles normally occupied by human beings soon spilled out from it-narratives into the religious press at large. RTS magazines such as The Visitor (1833), The Weekly Visitor (1836) and The Monthly Messenger (1844) figure themselves as persons paying social calls, not as objects being bought and sold. $^{\mathrm{vi}}$ Harlan Beach's The Cross in the Land of the Trident, Or, India from a Missionary Point of View postulates that "a good book is a cheap but very effective missionary" (Beach 104). The young hero of another RTS publication, coming across a bible in his new home, "recognised in a moment by its binding; and a feeling of joy came over him, as if an old friend had met him" (Millington 52). The promise of the Girl's Own Paper (published by the RTS from 1880 onward) to be "to its readers a guardian, instructor, companion, and friend" (report of the Committee, 1880, quoted Green 128)] borrows doubly from the logic of the it-narrative: in anthropomorphizing the book and in relocating agency from persons to objects.

More specifically, reviewers trying to describe the material attributes of books find a ready-made vocabulary in the it-narrative--or at least, this seems like the most plausible explanation for the pronouns in a 1846 review of a volume newly reissued in a tenpenny binding, where the Baptist Magazine remarks archly that now "he appears in clothing which will facilitate his reception into good company, and conduce to his preservation from the casualties of the way" (quoted Fyfe 159). To make books narratable was to make them human--and still is, to judge from scholarly titles like "The Biography of a Book" (the first chapter of Robert Darnton's The Business of Enlightenment) or from Cathy Davidson's play on italics in "The Life and Times of Charlotte Temple: The Biography of a Book". vii

The master trope of book history has always been personification. Elizabeth Eisenstein's Printing Press as an Agent of Change, Jerome McGann's Asocialization of texts@ and Paul Duguid's Social Life of Information anthropomorphize books as thoroughly as any it-narrative does. Both draw on the long tradition of users ventriloquizing books, like the inscription in one early modern copy of The Treasury of Amadis of France which reads "Dale Havers oweth me / he is my veri tenet [owner] / and I this booke confesse to be / quicunque me invenit [whoever finds me]" (Sherman 17). Outside of the object narrative's covers, no book speaks for itself. But the speech produced in (and by) its pages may provide one model for the stories that get told about books -- and maybe even about their users. 
Adams, Thomas R., and Nicolas Barker. "A New Model for the Study of the Book." In A Potencie of Life: Books in Society. Ed. Nicolas Barker. London: British Library, 1993. 543.

"Adventures of a Quire of Paper." London Magazine Aug-Oct. 1779: 355-38; 95-98; 448-52.

Appadurai, Arjun. "Introduction: Commodities and the Politics of Value." In The Social Life of Things: Commodities in Cultural Perspective. Ed. Arjun Appadurai. Cambridge: Cambridge University Press, 1986. 3-63.

Beach, Harlan Page. The Cross in the Land of the Trident, or, India from a Missionary Point of View. London: Religious Tract Society, 1896.

Biernacki, Richard. "Method and Metaphor after the New Cultural History." In Beyond the Cultural Turn : New Directions in the Study of Society and Culture. Eds. Victoria E. Bonnell and Lynn Avery Hunt. Berkeley, Calif.: University of California Press, 1999. xi, 350.

Blair, Ann. "Note Taking as an Art of Transmission." Critical Inquiry 31.1 (2004): 85-107.

Blair, Ann, and Peter Stallybrass. Mediating Information 1450-1800. Mediating enlightenment, past and present. (ms.)

Brown, Matthew. "Books, Things, Mary Rowlandson, Us." Harvard Humanities Center, 2007. Carey, Annie. The History of a Book. Cassell, Petter and Galpin, [1873].

Chartier, Roger. The Order of Books. Cambridge: Polity Press, 1994.

Collins, Paul. "You and Your Dumb Friends." Believer March 2004.

Darnton, Robert. The Business of Enlightenment: A Publishing History of the Encyclopédie, 1775-1800. Cambridge: Harvard University Press, 1979.

---. "What Is the History of Books?" In The Book History Reader. Eds. David Finkelstein and Alistair McCleery. London: Routledge, 2002.

Daston, Lorraine. "Taking Note(S)." ISIS: Journal of the History of Science in Society 95.3 (2004): 443-48.

Davidson, Cathy. "The Life and Times of Charlotte Temple: The Biography of a Book." In Reading in America: Literature and Social History. Ed. Cathy Davidson. Baltimore: Johns Hopkins University Press, 1989. 157-79.

Dickens, Charles. David Copperfield. Ed. Jeremy Tambling. New York: Penguin, 1996.

Duguid, Paul. The Quality of Information: High-Tech Supply and Low-Tech Command, 2007.

Eliot, George. The Mill on the Floss. Ed. A. S. Byatt. Harmondsworth: Penguin, 2003.

Festa, Lynn M. Sentimental Figures of Empire in Eighteenth-Century Britain and France. Baltimore: Johns Hopkins University Press, 2006.

Fliegelman, Jay. Belongings: Dramas of American Book Ownership, 1660-1860(unpublished ms.)

Flint, Christopher. "Speaking Objects: The Circulation of Stories in Eighteenth-Century Prose Fiction." PMLA 113.2 (1998): 212-26.

Fyfe, Aileen. Science and Salvation : Evangelical Popular Science Publishing in Victorian Britain. Chicago: University of Chicago Press, 2004.

Gates, Henry Louis. The Signifying Monkey : A Theory of Afro-American Literary Criticism. New York: Oxford University Press, 1988.

Green, Samuel G. The Story of the Religious Tract Society for One Hundred Years. London: Religious Tract Society, 1899. 
History of a Bible. Ballston Spa [N.Y.]: James Comstock, 1811.

The History of a Religious Tract Supposed to Be Related by Itself. London: Printed by W. Nicholson, for Williams \& Smith, 1806.

"The History of an Old Pocket Bible." Cottage Magazine; or, Plain Christian's Library MarchDecember 1812.

Hofmeyr, Isabel, and Sarah Nuttall. "The Book in Africa." Current Writing 13.2 (2001): 1-8.

Howsam, Leslie. Cheap Bibles : Nineteenth-Century Publishing and the British and Foreign Bible Society. Cambridge Studies in Publishing and Printing History. Cambridge [England]; New York: Cambridge University Press, 1991.

Jameson, Fredric. The Political Unconscious: Narrative as a Socially Symbolic Act. Ithaca: Cornell University Press, 1981.

Johnstone, Charles, and Malcolm J. Bosse. Chrysal. 1760-1765. The Novel, 1720-1805; 5.4 vols. New York: Garland Pub., 1979.

Kopytoff, Igor. "The Cultural Biography of Things." In The Social Life of Things: Commodities in Cultural Perspective. Ed. Arjun Appadurai. Cambridge: Cambridge University Press, 1986. 64-94.

Lamb, Jonathan. "Modern Metamorphoses and Disgraceful Tales." Critical Inquiry 28 (2001): $133-66$.

Latham, Sean, and Robert Scholes. "The Rise of Periodical Studies." PMLA 121 (2006): 517-31.

Levine, George. The Realistic Imagination : English Fiction from Frankenstein to Lady Chatterley. Chicago: University of Chicago Press, 1981.

"The Life and Adventures of a Number of Godey's Lady's Book. Addressed Particularly to Borrowers, Having Been Taken Down in Short-Hand from a Narration Made by Itself, When the Unfortunate Creature Was in a Dilapidated State, from the Treatment Received at the Hands of Cruel Oppressors." Godey's Magazine November 1855: 425-27.

Lupton, Christina. "The Knowing Book: Authors, It-Narratives, and Objectification in the Eighteenth Century." Novel 39 (2006): 402-20.

Marcus, Sharon. Between Women : Friendship, Desire, and Marriage in Victorian England. Princeton: Princeton University Press, 2007.

---. "The Profession of the Author: Abstraction, Advertising, and Jane Eyre." PMLA 110.2 (1995): 206-19.

McDonald, Peter. "Ideas of the Book and Histories of Literature: After Theory?" PMLA 121 (2006): 214-228

Millington, Thomas Street. Straight to the Mark. London: Religious Tract Society, 1883.

Moretti, Franco. Graphs, Maps, Trees : Abstract Models for a Literary History. London ; New York: Verso, 2005.

Plotz, John. Portable Property: Victorian Culture on the Move. Princeton University Press, 2008.

Sargent, George Etell. The Story of a Pocket Bible. London: The Religious Tract Society, [1859?].

Sedgwick, Eve Kosofsky. Touching Feeling: Affect, Pedagogy, Performativity. Durham: Duke University Press, 2003.

Sherman, William H. Used Books : Marking Readers in Renaissance England. Material Texts. Philadelphia: University of Pennsylvania Press, 2008.

St. Clair, William. The Reading Nation in the Romantic Period. Cambridge: Cambridge University Press, 2004. 
i. The article dates to 1991; I owe the reference to Richard Biernacki, "Method and Metaphor after the New Cultural History," Beyond the Cultural Turn : New Directions in the Study of Society and Culture, eds. Victoria E. Bonnell and Lynn Avery Hunt (Berkeley, Calif.: University of California Press, 1999) 74. For comments and bibliographical references, I'd like to thank Ellen Garvey, Sol Kim-Bentley, Maia McAleavey, Yoon Sun Lee, John Plotz, Peter Stallybrass, and Ramie Targoff.

ii. On the place of smell in book history, see Sean Latham and Robert Scholes, "The Rise of Periodical Studies," PMLA 121 (2006): 526.

iii. As Matthew Brown points out, the one category of object that scholars of material culture shy away from is the book. Even their successors, "thing theorists" like Bill Brown, ask how books represent things, not how books are things. Matthew Brown, "Books, Things, Mary Rowlandson, Us," (Harvard Humanities Center: 2007), vol.

iv. "Cheap Books," Christian Spectator (July 1846): 146, qtd. Aileen Fyfe, Science and Salvation : Evangelical Popular Science Publishing in Victorian Britain (Chicago: University of Chicago Press, 2004) 159.

1. Thanks to Ellen Garvey for this reference.

v. The it-narrative might then help explain George Levine's argument (building on Alexander Welsh's similar reading of Scott) that "it is one of the curious facts about the most virtuous heroes and heroines of nineteenth-century English realist fiction that they are inefficacious, inactive people. Their fullest energies are expended only (if at all) in response to external threat, in the preservation of familial and communal ties." George Levine, The Realistic Imagination : English Fiction from Frankenstein to Lady Chatterley (Chicago: University of Chicago Press, 1981) 33.

vi. See also Aileen Fyfe's argument that the evangelical press praised tracts for their ability to reach places where middle-class bodies could not safely venture. Aileen Fyfe, Science and Salvation : Evangelical Popular Science Publishing in Victorian Britain (Chicago: University of Chicago Press, 2004) 29.

vii. Robert Darnton, The Business of Enlightenment: A Publishing History of the Encyclopédie, 1775-1800 (Cambridge: Harvard University Press, 1979), Cathy Davidson, "The Life and Times of Charlotte Temple: The Biography of a Book.," Reading in America: Literature and Social History, ed. Cathy Davidson (Baltimore: Johns Hopkins University Press, 1989). Not that this metaphor is confined to books in particular: witness Igor Kopytoff's essay "The Cultural Biography of Things" The Social Life of Things: Commodities in Cultural Perspective, ed. Arjun Appadurai (Cambridge: Cambridge University Press, 1986). For the longer history of the "talking book," see Henry Louis Gates, The Signifying Monkey : A Theory of Afro-American Literary Criticism (New York: Oxford University Press, 1988) 152-69. 